\title{
Purple coneflower viruses: species diversity and harmfulness
}

\author{
A. A. Dunich, L. T. Mishchenko \\ Educational and Scientific Centre «Institute of Biology», \\ Taras Shevchenko National University of Kyiv \\ 64/13, Volodymyrska Str., Kyiv, Ukraine, 01601 \\ korenevochka@mail.ru
}

\begin{abstract}
Viral diseases became an actual problem in medicinal plants cultivation. The number of viruses known to infect purple coneflower increased significantly in the last years in many countries. However, there is no any review about the viral diseases of this valuable medicinal crop. Therefore, the aim of this article is to summarize the main information about the viruses affecting purple coneflower plants (Echinacea purpurea L. Moench.). An analysis of the literature data showed that purple coneflower could be infected by 10 viruses. These viruses belong to the families Bromoviridae, Bunyaviridae, Secoviridae, Potyviridae, Virgaviridae, and almost all of them are considered to be highly harmful plant viruses. Additionally, four of them (TMV, TSWV, CMV, PVY) are in the top 10 of the most economically important plant viruses in the world and occupy the first places. The data from a few countries show that the viral diseases of purple coneflower are becoming more severe from year to year. The appearance of new viruses is registered on coneflower every year that complicates prognosis and risk estimation of epiphytoties in these regions which, for example, were revealed in Bulgaria, Lithuania and Ukraine. This review presents the detailed symptoms of the viral diseases in purple coneflower, the main properties of each virus and data about their harmful effect on the plant metabolism and on the quality of raw material (the concentration of biologically active substances and heavy metals in plants).
\end{abstract}

Key w or d s: purple coneflower, plant viruses, species diversity, biologically active substances, heavy metals.

\section{Introduction}

Nowadays demand for herbal medicines is constantly increasing. Purple coneflower (Echinacea purpurea (L.) Moench.) is an important medicinal plant. This plant is used for treating more than 70 disorders in humans and is a component of approximately 300 herbal medicines [1]. Besides that, it is also used as ornamental, melliferous and essential oil plant. Purple coneflower is an herbaceous perennial plant of Asteraceae family. It is native to the eastern and southern USA [2].

This herb is cultivated in the north-western states of America, in western Canada, Australia, New Zealand, southern America, Europe and also was in- troduced in Ukraine. The difficulty of its cultivating is connected with the condition requirements for the plant. Unlike the natural phytocenosis, during accommodating to agrocenosis conditions the herbs are becoming more wasted and susceptible to plant pathogens of different etiology. Besides that, purple coneflower is a perennial plant that causes accumulation of pathogens, including viruses.

Regardless of the value of the purple coneflower in different areas, there is no review on its viruses all over the world. So, in this article we present a review that summarizes the main information about the viruses affecting purple coneflower plants all around the world.

There are data about diseases of purple coneflower caused by 10 viruses (Tabl. 1).

(C) 2015 A. A. Dunich et al.; Published by the Institute of Molecular Biology and Genetics, NAS of Ukraine on behalf of Biopolymers and Cell. This is an Open Access article distributed under the terms of the Creative Commons Attribution License (http://creativecommons.org/licenses/by/4.0/), which permits unrestricted reuse, distribution, and reproduction in any medium, provided the original work is properly cited 


\section{Viruses of Bromoviridae family}

Alfalfa mosaic virus, AMV. Alfalfa mosaic virus is a member of Alfamovirus genus, Bromoviridae family. AMV has a wide host range. This virus can naturally infect many herbaceous and some woody plant hosts (150 species of 22 families) and is transmissible to over 430 species of 51 dicotyledonous families [25]. AMV can cause various mosaics, mottles, and malformations in alfalfa (Medicago sativa), yellowing of leaves in pea (Pisum sativum), calico and tuber necrosis in potato (Solanum tuberosum), and various symptoms in tobacco (Nicotiana tabacum) [26, 27]. Sixteen species of aphids, including Myzus persicae, can transmit AMV in a non-persistent manner [28]. AMV can be also transmitted by potato pollen and by seed [29].
In 2008-2009, Alfalfa mosaic virus was detected in Bulgaria in $55.5 \%$ of tested purple coneflower samples [3, 4]. AMV caused spotting and dwarfing of the purple coneflower leaves. The virus was detected in co-infection with TMV and CMV. The impact of the disease caused by CMV, AMV and TMV on the coneflower yield was also determined. Infected herbs had lower weight and number of leaves, racemes and produced seeds half as much.

\section{Cucumber mosaic virus, CMV}

Cucumber mosaic virus causes substantial agronomic yield losses in many crops in the world, probably has one of the broadest host range among plant viruses. CMV is a type member of the genus Cucumovirus, family Bromoviridae and infects more than 1,000 plant

Table 1. Viruses that infect purple coneflower in the world

\begin{tabular}{|c|c|c|c|c|}
\hline Virus name & Acronym & Genus, family & $\begin{array}{c}\text { Detection } \\
\text { on coneflower, } \\
\text { country }\end{array}$ & References \\
\hline Alfalfa mosaic virus & AMV & Alfamovirus, Bromoviridae & Bulgaria & {$[3,4]$} \\
\hline Broad bean wilt virus 2 & BBWV-2 & Fabavirus, Secoviridae & China & {$[5]$} \\
\hline \multirow[t]{10}{*}{ Cucumber mosaic virus } & CMV & Cucumovirus, Bromoviridae & Germany & {$[6]$} \\
\hline & & & New Zealand & {$[7,8]$} \\
\hline & & & Japan & [9] \\
\hline & & & Italy & {$[10-12]$} \\
\hline & & & USA & {$[13]$} \\
\hline & & & Hungary & {$[15]$} \\
\hline & & & Belarus & {$[16]$} \\
\hline & & & China & {$[22]$} \\
\hline & & & Bulgaria & {$[3,4]$} \\
\hline & & & Ukraine & {$[17]$} \\
\hline Impatiens necrotic spot virus & INSV & Tospovirus, Bunyaviridae & Lithuania & {$[18]$} \\
\hline \multirow[t]{3}{*}{ Potato virus $Y$} & PVY & Potyvirus, Potyviridae & Hungary & {$[14]$} \\
\hline & & & Bulgaria & {$[3,4]$} \\
\hline & & & Ukraine & {$[19]$} \\
\hline \multirow[t]{2}{*}{ Tobacco mosaic virus } & TMV & Tobamovirus, Virgaviridae & Bulgaria & {$[4]$} \\
\hline & & & Hungary & [14] \\
\hline Tobacco rattle virus & TRV & Tobravirus, Virgaviridae & Lithuania & {$[18,20]$} \\
\hline Tobacco ringspot virus & TRSV & Nepovirus, Secoviridae & Lithuania & {$[20,21]$} \\
\hline Tomato ringspot virus & ToRSV & Nepovirus, Secoviridae & Lithuania & {$[22]$} \\
\hline \multirow[t]{4}{*}{ Tomato spotted wilt virus } & TSWV & Tospovirus, Bunyaviridae & Lithuania & {$[18]$} \\
\hline & & & Hungary & {$[14]$} \\
\hline & & & Bulgaria & {$[4,23]$} \\
\hline & & & Ukraine & {$[24]$} \\
\hline
\end{tabular}


species from more than 86 families, including monocots and dicots [25]. The host range includes different crops and numerous wild plants, which are important for the annual persistence of the virus in the open field.

CMV is transmitted by aphides (Aphididae; more than 60 species, including Acyrthosiphon pisum, Aphis craccivora and Myzus persicae) in non-persistent manner, by mechanical inoculation and seeds $[25,30]$.

The earliest report on CMV affecting purple coneflower was in 1964 in Germany [6]. CMV-infected purple coneflower was revealed in Belarus and reported as a weedy host for the virus [15], New Zealand with the symptoms of yellow mottling on the leaves $[7,8]$, and also in the US, where the disease was accompanied with ringspots and leaf deformation [13].

In 1993, CMV disease of Echinacea purpurea was observed in Japan [9]. Coneflower plants showed mosaic symptoms in the leaves.

Yamamoto et al. studied a host range of an isolate of CMV (39 plant species were inoculated) [9]. It was demonstrated that 18 species including Echinacea purpurea, Lycopersicon esculentum, Petunia hybrid, Capsicum annum, Pisum sativum, Vicia faba, Cucumis sativus, Nicotiana tabacum, N. glutinosa were systemically infected by CMV, but the virus could not be readily transmitted to Cucumis sativus. Eighteen species such as: Citrullus lanatus, Cucumis melo, C. melo (makuwa), C. melo (conomon), Cucurbita maxima, C. moschata, C. pepo, Vigna sesquipedalis, Chenopodium quinoa, Chenopodium amaranticolor were locally infected. It was the first report about the viral disease of purple coneflower in Japan and the authors proposed to name this disease as 'Echinacea mosaic disease' [9].

In Italy, CMV has been detected in the plants of purple coneflower for years. The disease has the symptoms of yellow mosaic, variegation on the leaves which were often malformed and with bullas. The petals showed contractions, deformations and mottling [10, 11]. In 2009, CMV-infected plants showed stunting; leaves with yellow mosaics, ring, line patterns and malformations; small flowers with pale stripes on red petals [12]. Moreover, Italian scientists have studied genetic modifications of the CMV isolates, taken from aromatic, officinal and ornamental plants in the Northern Italy. They made a sequence analysis of the movement protein gene of CMV isolate from purple coneflower and its comparison with the isolates from other countries [31]. A phylogenetic analysis showed that CMV isolate from Echinacea purpurea from Italy (EU 432180) belonged to the subgroup IA and was genetically closer to the Italian isolate CMV-LAV (EU432182) from Lavandula officinalis and Hungarian NS isolate from Nicotiana glutinosa (AJ511990). The comparison of nonsynonymous and synonymous substitutions suggested that $30 \%$ of amino acid sites were under negative selection and only one was under positive selection. Phylogenetic, nucleotide diversity and genetic differentiation analyses suggested that longdistance migration plays a role in the evolution and determination of the genetic structure and diversity of CMV in northern Italy and other regions.

CMV was also revealed in Hungary in mixed infection with PVY, TMV i TSWV [14].

The disease of purple coneflower with the symptoms of yellow mosaics on the leaves was also revealed in China. On the basis of virion structure, the biological and serological properties were determined that were caused by CMV [16]. The nucleotide and amino acid sequence analysis of the RNA 2-1-1 fragments showed the 94.5 and $98.1 \%$ identity with the standard isolates of Fny subgroup as well as 77.7 and $82.5 \%$ identity with the standard isolate Q from the subgroup II [32].

In Bulgaria, $45.5 \%$ of purple coneflower plants with viral symptoms were determined as infected by CMV [4]. The symptoms were light-green spots on the leaves with curly laminas due to the different growth of pale green and dark green areas of the leaves (Fig. 1).

Dikova et al. showed that economically important viruses for the E. purpurea cultivation in Bulgaria are those, transmitted by aphids: AMV and CMV as well as the mechanically transmitted TMV [4]. These three viruses were widespread in over $45 \%$ of plants and caused the symptoms of spotting and even of mosaic on the leaves. It is interesting to mention that mixed infection by CMV, AMV and TMV caused 

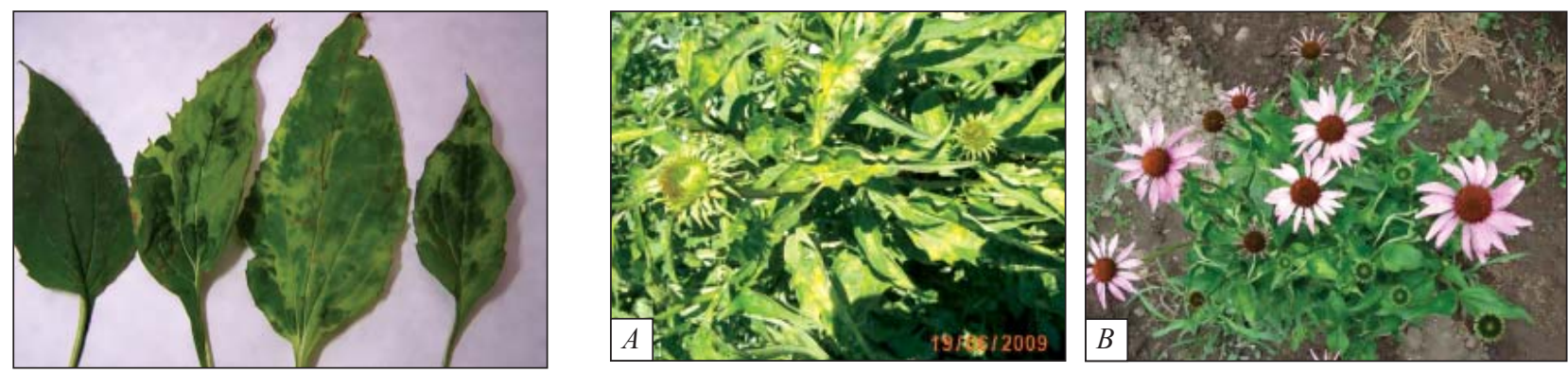

Fig. 1. Symptoms of mosaics on Echinacea purpurea leaves caused by Cucumber mosaic virus in Bulgaria (at the left - a symptomless leaf) [4]

Fig. 2. E. purpurea infected by CMV, AMV and TMV in Bulgaria: $A$ - spotting on the leaves; $B$ - dwarfed leaves and stunting [4]
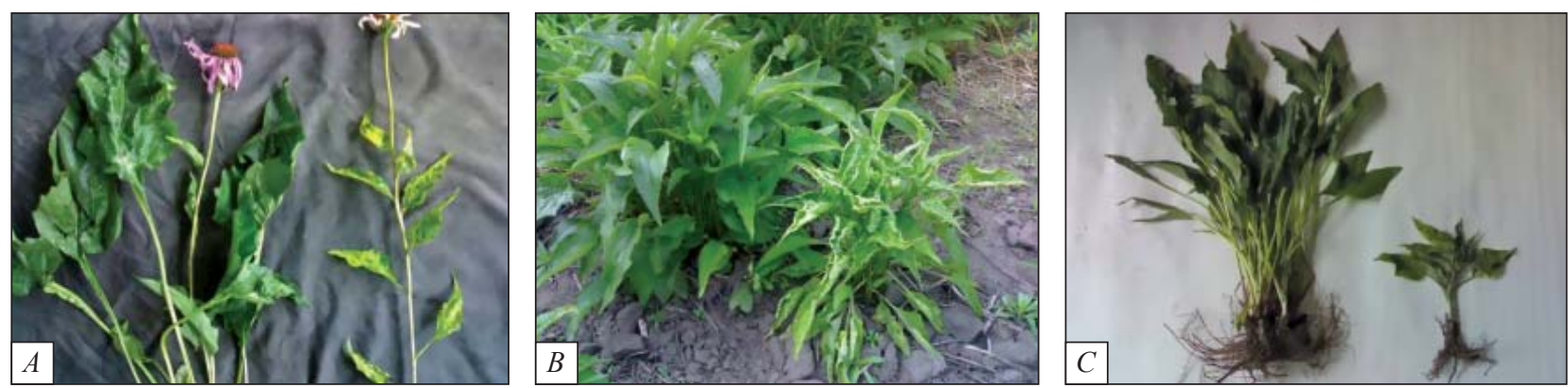

Fig. 3. Echinacea purpurea infected by CMV in Ukraine: on each photo at the left - healthy plant, at the right - virus infected plant [17, 33]
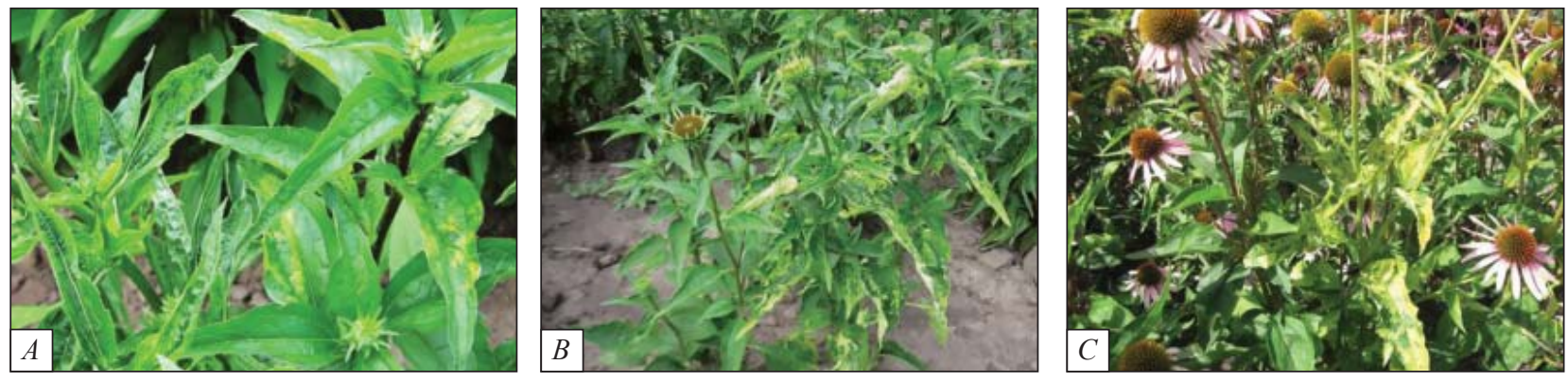

Fig. 4. Symptoms of TSWV infection on purple coneflower in Ukraine: $A$, $B$-phase of budding-initial blossoming; $C$-end of blossoming [19, 24, 61]

other symptoms - spotting and dwarfed coneflower leaves (Fig. 2).

Dikova and co-authors revealed that sprouts, containing viruses, grew from the purple coneflower roots, infected during the first year of twoand three- year old coneflower plantations showed the highest percentage of infection with spotted plants and dwarfing leaves and stems [3, 4]. They showed that the vector of CMV could be aphids Aphis gossypii Glover (cotton aphid) which were found in the trial fields with E. purpurea during April, May and June. These aphids were not observed at later stages of vegetation of E. purpurea plants in July and August.

In 2006-2009, epiphytoty of CMV on field-grown purple coneflower was registered in Ukraine [17, 33]. Monitoring of the plantations showed that $75 \%$ of the plants were with the symptoms of viral infection. The most typical symptom was chlorosis on the leaves accompanied by their size reduction (Fig. 3, A). 
It is noteworthy that these symptoms were revealed among the herbs of the $1^{\text {st }}$ year of cultivation as well as among those of the $2^{\text {nd }}-5^{\text {th }}$ years during both regeneration and blossoming periods. Also rolling, rasp-shape and leaf deformation were revealed on the $2^{\text {nd }}$ year plants (Fig. 3, B). In limited number of the cases, the plant stunting and the stunting of the root system have been observed (Fig. 3, C). Generally, it was observed that the virus symptoms were getting more pronounced during the last years.

The spherical particles were revealed in the purple coneflower plants $29.5 \pm 0.5 \mathrm{~nm}$ in diameter [17, 34]. The virus identification carried out by ELISA and the study of biological, physical and chemical properties of the virus proved that the plants were infected by CMV [17]. It was the first report about infection of purple coneflower by CMV in Ukraine.

Taking into consideration the data about species diversity of the viruses infecting purple coneflower in the world and those widely spread in Ukraine, the samples were also tested as to the presence of other viruses. The results of ELISA test indicated that in purple coneflower there were no antigens of the following viruses: TMV, AMV, TSWV, INSV, TRV, PVY, PVS, PVX, PVM, TAV, ArMV, TuMV, PePMV, WMV-2, and CGMMV [17].

\section{Viruses of Bunyaviridae family}

Tomato spotted wilt virus, TSWV, and Impatiens necrotic spot virus, INSV. TSWV and INSV are the members of genus Tospovirus. Initially INSV was considered to be another isolate of TSWV, but genetic studies proved that they are different virus species [35]. Tospoviruses are transmitted in a persistent and propagative manner exclusively by thrips (Thysanoptera: Thripidae) [36]. Transmission can also be achieved through infected plant sap. INSV and TSWV are mainly defined on the basis of their vector specificity, host range and symptoms of disease.

TSWV was reported to have a very broad host range including more than 1100 different species from more than 80 families [37]. The TSWV infection is characterized by different symptoms depending on the plant species $[38,39]$. TSWV causes severe diseases in numerous horticultural and agri- cultural crops. TSWV is the second among the top 10 of scientifically and economically important plant viruses in the world [40]. The distinguishing feature of this virus is an ability to infect many species: from 150announced in 1968 [41] to 650 announced in 1994 [42] and about 1100 plants from more than 80 families - in 2003 [37, 43]. The number of susceptible plants exposed to the risk to be infected by TSWV is growing nowadays. It can be explained by some features of epidemiology of this virus. There are innumerable infected weeds that serve as reservoirs for primary infection [38]. These plant sources perpetuate TSWV as important hosts for thrips vectors and serve as foci for subsequent movement and infection of susceptible crop plants [44]. TSWV is transmitted by thrips Frankliniella occidentalis, F. bispinosa, F. cephalica, F. gemina. F. fusca, F. intonsa, F. schultzei, F. setosus and Thrips tabaci $[25,36]$. TSWV is also transmitted by grafting; and is not transmitted by contact between plants, by seed and by pollen.

INSV has a narrower host range than TSWV. INSV infects more than 648 species including important horticultural and agricultural crops [25]. Its name indicates that the main symptom is necrotic spotting on the leaves. However, it is rather difficult to diagnose INSV as the symptoms can vary depending on the host and its age. The symptoms caused by INSV can be easily confused with those of other viruses, fungi and bacteria or nutrition disorders. It has been announced many years ago that flower thrips (Frankliniella occidentalis) are the only effective transmitter of INSV [45]. Moreover, INSV can be transmitted by other species Frankliniella $-F$. intonsa [46] and F. fusca [47].

In purple coneflower TSWV was detected in Europe (Lithuania, Bulgaria, Hungary and Ukraine). In Lithuania, TSWV on the purple coneflower was registered in co-infection with INSV [18].

In 2009-2010, TSWV was also revealed in Bulgaria on the purple coneflower plants [23]. The author described that TSWV caused yellow spotting on the purple coneflower leaves. TSWV was revealed in one plant with the symptoms on leaves typical for this virus - chlorotic dark red ring spots turning into 
brown necrotic lesions $[4,23]$. Thripses were found on E. purpurea racemes in single cases. The main species was Frankliniella occidentalis that appeared in May to July.

In 2012, purple coneflower disease caused by TSWV was revealed in Ukraine [24]. The symptoms of the disease were yellow spots, mosaics and leaf deformation during all vegetation phases. Light green mottling on the leaves during budding-initial blossoming (Fig. 4, $A, B$ ) turned into yellow mottling, that at the end of blossoming covered practically all lamina (Fig. 4, C).

The virions of the TSWV isolate were studied with the electron microscopy method and were $100 \pm$ $\pm 20 \mathrm{~nm}$ in diameter.

It was also studied whether the plant samples were infected by INSV taking into consideration that in Lithuania purple coneflower was infected with the complex of TSWV and INSV [18]. The ELISA results showed the absence of INSV in the coneflower plants [24].

\section{Viruses of Potyviridae family}

Potato virus Y, PVY. Potato virus $Y$ is a type member of the genus Potyvirus of family Potyviridae. It is common knowledge that this is one of the most widely spread and economically important pathogen with a broad range of susceptible plants from different families. Besides the potato it can infect tobacco, tomato, sweet pepper and many others. Nowadays PVY is the fifth among top 10 economically and scientifically important plant viruses [40]. The virus is transmitted by a vector in non-persistent manner (arthropods, insects of order Hemiptera, family Aphididae), by mechanical inoculation, by grafting. Transmitting by seeds and contact is plausible $[25,48]$.

In 2008 , only $3.13 \%$ of purple coneflower infected by the PVY+ CMV+AMV complex was revealed in Bulgaria. The symptoms were spotting and «dwarfed» leaves [3, 4]. In Hungary PVY was found in the co-infection with CMV, TMV and TSWV [14].

PVY was also detected in Ukraine in purple coneflower with the symptoms of leaf curling and deformation [19]. The samples of $2^{\text {nd }}$ and $3^{\text {rd }}$ years of cultivation were tested positive by RT-PCR.

\section{Viruses of Secoviridae family, Comovirinae subfamily}

Broad bean wilt virus 2, BBWV-2. BBWV-2 is a member of Fabavirus genus [49]. BBWV-2 spreads in African region, Eurasian region, Middle East, North American region, Pacific region, Australia and China. The virus is transmitted by a vector in a nonpersistent manner; an insect; Acyrthosiphon pisum, Aphis craccivora, A. faba, A. nasturtii, Macrosiphum euphorbiae, M. solanifolii, M. persicae; Aphididae. The virus is transmitted by mechanical inoculation and not transmitted by seeds.

In 2010, BBWV-2 was revealed on purple coneflower plantations in China. The symptoms were necroses, leaf rolling, yellow mosaics, and mosaics in leaves [5]. One plant sample with mosaics symptoms was tested positive in ELISA. Li et al. have studied the range of experimental hosts. Susceptible plant species for Chinese BBWV-2 isolate were Chenopodium quinoa (local lesions in inoculated leaves, systemic chlorotic mottle in upper leaves, deformation, and apical necrosis), C. amaranticolor (chlorotic local lesions, systemic mosaic and leaf distortion), Nicotiana benthamiana (systemic mosaics), Gomphrena globosa (local purple spots in inoculated leaves and systemic infection in upper leaves), Tetragonia expansa (local lesions, but no symptoms of systemic infection), Physalis floridana (systemic mosaics). No symptoms were observed on Capsicum annum, Datura stramonium, N. glutinosa, or N. tabacum cv. White Burley. Comparison with the sequences of other BBWV-2 isolates showed that the isolate from coneflower (No. JX070674) had approximately $99 \%$ nt identity ( $98 \%$ amino acid identity) with Chinese BBWV-2 isolate BC from Bupleurum chinense. This was the first report of BBWV-2 infecting purple coneflower in China and, to our knowledge, in the world.

Tobacco ringspot virus, TRSV and Tomato ringspot virus, ToRSV. TRSV and ToRSV belong to the subgroup A of genus Nepovirus and are serologically related viruses [25]. The nepoviruses have a wide host range, including both woody and herbaceous plants. TRSV causes significant disease in grape, soybean, tobacco, blueberry and members of $\mathrm{Cu}$ - 
curbitaceae family (melon, cucumber, squash, and pumpkin). Many other hosts infected naturally were found, including apple, pepper, cherry, papaya, various weeds and mint [50]. TRSV causes systemic chlorotic or necrotic ringspots, leaf deformation and stunting. The ToRSV host range is very similar to that of Tobacco ringspot nepovirus, except that it is much less important for fruit crops than ToRSV.

The nepoviruses are transmitted by the nematode Xiphinema americanum and other closely related Xiphinema spp [51]. TRSV is easily transmitted mechanically, by seeds and pollen $[52,53]$. TRSV and ToRSV have been reported in Europe, North America, Australia, Africa, India, Japan [3] and New Zealand [54], Lithuania [55] and Ukraine. TRSV is included in the list of quarantined pest [56].

Firstly ToRSV on the purple coneflower plants was revealed in Lithuania in 2000 [22] and TRSV in 2006 [21]. In 2003, the mixed infection of ToRSV and TRV was detected [18]. In 2008, Echinacea purpurea (L.) Moench exhibiting the symptoms of plant stunting, leaf malformation, various shaped chlorotic spots, ringspots was collected in the Botanical Garden of Vilnius University. According to the results obtained by the methods of test-plants, electron microscopy, DASELISA, and RT-PCR, the purple coneflower plants were affected by co-infection of TRSV and TRV [21].

\section{Viruses of Virgaviridae family}

Tobacco rattle virus, TRV. Tobacco rattle virus is a type member of Tobravirus genus, Virgaviridae family. For the first time this virus was revealed in 1931 in Germany on tobacco. TRV is transmitted by a vector (nematodes; family Trichodoridae; Paratrichodorus allius, P. anemones, P. christiei, P. nanus, P. pachydermus, $P$. teres, Trichodorus minor, $T$. primitivus, $T$. viruliferus). The virus is transmitted by mechanical inoculation, grafting and seeds; not transmitted by contact between hosts.

Geographically TRV has been found throughout Europe, New Zealand, North America and Japan. TRV has one of the widest host ranges among all the plant viruses. Natural infection has been reported in more than 100 plant species [25]. About 400 species in more than 50 families can be infected by sap in- oculation [57]. TRV has continuously been a significant potato pathogen causing corky ringspots in potato tubers, which renders the crop unmarketable [58]. Additionally, infection by TRV may cause a loss of vigor and yield in tomato, tobacco, sugar beet, spinach, artichoke, celery, pepper and lettuce.

In 2003, TRV was detected in the purple coneflower in co-infection with ToRSV and in 2008 with TRSV in Lithuania $[18,20]$. This is the only report about infecting purple coneflower plants by TRV in the world.

Tobacco mosaic virus, TMV is the type member of genus Tobamovirus. TMV is thermostable, the thermal inactivation point is $95{ }^{\circ} \mathrm{C}$. It is extremely persistent in an external environment. The virus is not transmitted by a vector. Virus is transmitted by mechanical inoculation, grafting, contact between hosts, by seeds (occasionally transmitted through the testa, but not through the embryo), not transmitted by pollen [25].

TMV has a wide host range (more than 350 species), which includes various vegetables (beet, pepper, eggplant, potato, spinach, tomato), agricultural crops (tobacco, beans, grapes, apple-tree), decorative plants (petunia, phloxes, zinnia), annual and perennial weeds. It is one of the most contagious plant viruses. The sources of infection are plant residues, seeds, and soil in which the virus does not lose viability for over 22 months. The symptoms vary depending on the virus strain, species, phase of infection, environmental conditions. A mixed infection of Tobacco mosaic virus with other viruses (Potato virus X, Potato virus Y, Cucumber mosaic virus) causes brown wide and narrow stripes on fruits, leaves, stems and petioles which die off in course of time. TMV is distributed in Eurasia, revealed in Argentina, Australia, Germany, France, Hungary, Iceland, India, Italy, Japan, Peru, Kenya, Spain, USA, and Great Britain [25].

TMV in purple coneflower plants was revealed in Hungary in 2006 [14] and in Bulgaria [4], where it was observed in a co-infection with AMV and CMV. TMV caused the mosaics symptoms and spotting and is considered to be one of the most economically important viruses infecting purple coneflower (Fig. 2). Dikova et al. found that the virus infected coneflow- 
er plants were lower, with smaller number of leaves and racemes in comparison with the control plants [4]. The differences in the sizes of organs affected the yield. So, the yield of leaf mass (herba) from the virus infected plants was twice to several times lower in comparison with the symptomless samples. It was noted that more than half of the purple coneflower plants died over a period of three years. Such perishing was due to different factors - viruses, phytoplasma pathogens and environmental conditions (dry soil, high or low temperature). In order to minimize the damage, caused by viruses, the purple coneflower fields should be isolated from the vegetable and flower plants [4].

\section{Unidentified viruses}

Rod-shaped virions $40 \pm 5,70 \pm 5$ and $130 \pm 30 \mathrm{~nm}$ long, 17-20 nm wide were revealed in the leaves of purple coneflower cultivated in Ukraine (Fig. 5).

Viruses, presented in Fig. 5, are rod-shaped with distinct axial canal. Morphologically they are similar to the viruses of Virgaviridae family, which includes six genera: Hordeivirus, Furovirus, Pecluvirus, Pomovirus, Tobamovirus, and Tobravirus. However, among mentioned genera, the first four have a very narrow host range. The described viruses cannot be considered as tobamoviruses as the length of virions differs substantially. Morphologically they are closer to tobraviruses. Additionally, the infecting purple coneflower plants by Tobacco rattle virus which belongs to this family was registered in Lithuania $[18,20]$. Tobraviruses are transmitted by the nematodes Trichodorus and Paratrichodorus (Trichodoridae), which are widespread in Ukraine [59]. However, the results of ELISA tests indicated that this rod-shaped virus is not the TRV (unpublished data). Maybe, purple coneflower in Ukraine was affected by other members of the genus Tobravirus: Pea early browning virus, PEBV or Pepper ringspot virus, PepRSV. However, testing coneflower plants on the antigens of PEBV and PepRSV was not conducted. There are the data about infecting atypical plants by hordeiviruses which is known to have a very narrow host range which includes mainly cereals. Beczner et al. noted that in Hungary the member of Hordeivirus genus Lychnis ringspot virus (LRSV-M) infected mint plants (Mentha longifolia Huds) [60]. The virus is transmitted mechanically, by seeds and pollen. Taking this into consideration, we should not eliminate the possibility that purple coneflower can be infected by hordeiviruses in Ukraine.

\section{Effect of plant viruses \\ on the general links of plants metabolism}

For today, despite numerous researches devoted to the study of viral diseases of plants, the mechanisms of development of the pathological process remain unexposed and, at the same time, actual for many scientists. Study on the effects, caused by a viral infection, at the level of cells and their compartments as well as at the organism level is important for understanding the mechanisms of co-operation of the virus with a plant. The research of influence of viral infection on the basic links of metabolism is of special interest as they provide the plant with plastic and power substances that are necessary for normal development and vital functions.

Many scientists investigate an influence of viruses on the photosynthetic apparatus of plants, in fact the level of photosynthesis is one of basic indexes of the plant normal development and productivity, and thus, the plant: resistance to the infections $[17,61-$ 63]. They revealed a substantial reduction in the concentration of both chlorophylls $a$ and $b$ as well as of carotenoids in the leaves of Lophanthus anisatus, Arctium lappa and Echinacea purpurea under viral infection. The chlorophyll $a$ content in the leaves of virus infected Lophanthus anisatus plants was by $35 \%$ lower, in comparison with the healthy standards. This tendency was observed also at research of concentration of chlorophyll $b$, that in sick plants diminished three times (by $31.4 \%$ in comparison with the control). The carotenoids concentration diminished by $32 \%$ in the virus infected giant hyssop plants [64]. A substantial decline in the photosynthetic pigments content under the action of viral infection was found for the burdock plants too. Concentration of chlorophyll $a$ was less by $69.7 \%$ compared with the control, chlorophyll $b-$ by $73.0 \%$, 
sum of carotenoids - by $44.6 \%$. In leaves of the CMV-infected Echinacea purpurea plants content of chlorophyll $a$ was by $50.5 \%$ lower, than in healthy plants, and content of chlorophyll $b$ and sum of carotenoids - by $68.9 \%$ and $41.3 \%$, accordingly [61]. It is necessary to mark that the most substantial decline in the content of these pigments was revealed in purple coneflower plants that testify about high harmfulness of the virus.

Viruses can influence the metabolism of plants differently, including the content of carbohydrates in leaves. Some viruses have insufficient effect on carbohydrates in leaves, whereas others can change both speed of synthesis and speed of their movement in a plant. It was revealed that in leaves of the infected ginseng plants the content of saccharides was higher compared with the healthy plants: monosaccharides - by $26 \%$, sucrose - by $102 \%$, sum of sugars - by $57 \%$ [17]. One of suggestions of a reason of glucose, fructose and sucrose accumulation in the leaves of plants infected by a virus was the violation of their outflow from phloem that conduces to the development of gummosis. Later Watson M.A. and Watson D.J. made a conclusion that the carbohydrates accumulation in leaves of the sugar beet staggered by the Beet yellow virus is conditioned not by blocking the carbohydrates outflow from leaves but by the influence of the virus on the cells of leaf cells and, maybe, related to the changes in the activity of the enzyme systems that control the interconversion of different forms of carbohydrates [65]. It was shown that viral infection conduces to the increase in quantitative content of carbohydrates in leaves and stems of ginseng plants (Panax ginseng C.A. Meyer): monosaccharides - on $26 \%$, sucrose - on $102 \%$, sum of saccharides - on $57 \%$ in comparison with the uninfected plants [17]. Unlike ginseng, in purple coneflower plants infected with CMV there was registered decline of content of carbohydrates - monosaccharides - by $58.8 \%$, sum of saccharides - by $7.7 \%$ [17]. Such controversial data on the carbohydrates concentration for these two herbs (coneflower, ginseng) at a viral infection can be explained by the fact that ginseng was infected by a less virulent virus, than culture of

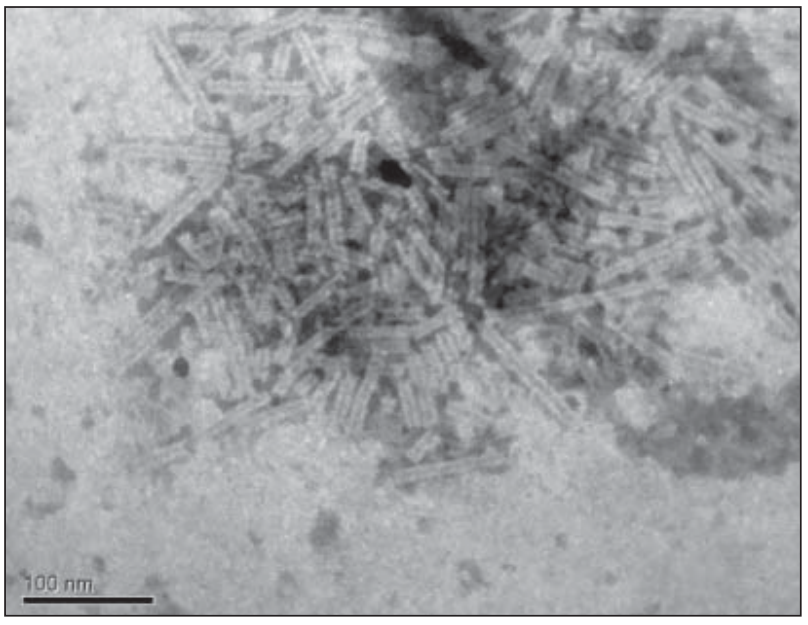

Fig. 5. Rod-shaped virions from Echinacea purpurea cultivated in Ukraine [19, 61]

Echinacea purpurea. Probably, in the last case a tendency to the accumulation of sugars is counterbalanced by more active influence of viruses on the photosynthetic apparatus of a plant.

Danger and harmfulness of viral diseases increases due to some factors. Firstly, a viral infection negatively affects a height and development of plants, represses the process of forming productive stems and reproductive organs. Secondly, a viral disease makes weakened plants more vulnerable to other pathogens, in particular, by fungi that cause the root rot. Thirdly, a viral infection often passes and spread by vectors, especially by insects, that is a difficult and ecologically dangerous challenge.

\section{Effect of plant viruses on the raw material quality}

Except a significant effect of viruses on the yield of purple coneflower and other medicinal plants [4, 17], it was proved that these pathogens reduce the content of biologically active substances in medicinal plants. In Italy, virologists showed that CMV reduced the content of some lipophilic compounds in the purple coneflower plants $[10,11,66]$. The infected materials from Echinacea purpurea afforded a lower oil content and significant quantitative variations in the oil composition when the plants were infected by CMV [67]. It was shown that the CMV infection led to a 
decrease in the concentration of hydrocinnamic acids sum, caftaric and cichoric acids sum in coneflower plants, sometimes to the level below the norms regulated by the State Pharmacopoeia [61, 68, 69]. The polysaccharides content significantly reduced, too $[17,69]$. Pellati with colleagues have studied the content of the secondary metabolites, such as coffee acid derivatives, alcamides and essential oil in purple coneflower affected by CMV and phytoplasma 16SrIX-C [12]. It was noted, that in the plants infected by both pathogens, the concentration of cichoric acid substantially diminished. Viral infection reduces the content of alkamides and some components of essential oil [12]. Regarding the main alkamide, dodeca-2E,4E, 8Z,10E / Z-tetraenoic acid isobutylamide, a significant decrease in the content of this secondary metabolite was observed in virus-infected plants in comparison with healthy plants, whereas in the phytoplasma-infected sample the variation of this secondary metabolite was not appreciable.

Indisputable negative CMV influence on the quality of raw material was also revealed for some other medicinal plants. For example, it was shown that the CMV infection reduced significantly the quantitative yield of essential oil in Agastache anethiodora and caused changes in the relative composition of the main components: pulegone, menthone, iso-menthone, methyl chavicole and limonene [70].

Negative influence on the raw material quality is also shown for some other viruses. It was discovered that AMV reduces the essential oil secretion in the lavender plants [71], Peppermint stunt virus - in the mint plants [72] and BBWV-1 reduces quantitative and qualitative content of essential oil in the Thymus vulgaris [73] and Salvia sclarea plants [74, 75]. A decrease of the basic BAS in the infected plants is discovered also for ginseng (Panax ginseng C.A. Meyer). It was shown that the content of triterpene glycosides (saponins) in the roots of infected ginseng was 5.6\%, i.e. by $2.0 \%$ less than in the healthy plants [17]. Although such raw material remains suitable for pharmacology, however, such substantial worsening of the raw material quality can have catastrophic consequences taking into account difficulty of cultivating this crop in Ukraine.
Except the influence of viruses on therapeutically active substances in the plants it was shown that these pathogens worsened the quality of raw material for drug production. So, upon the action of viral infection it was revealed the accumulation of some heavy metals in medicinal plants in amounts which exceed maximum allowable concentrations (MAC) in food products. It is necessary to notice that the content of hightoxic elements (As, V, Sb, Cr, Fe) in the TSWVinfected purple coneflower plants exceeded MAC in $1.2,7,2.3,2.5$ and 3.4 times respectively, unlike the healthy plants, the concentration of these metals [in which] was within the limits of norm [24, 76].

In the virus infected Lophanthus anisatus plants the concentration of $\mathrm{Pb}, \mathrm{As}, \mathrm{Cu}, \mathrm{Zn}, \mathrm{V}, \mathrm{Ni}, \mathrm{Fe}$ and $\mathrm{Al}$ exceeded MAC in $1.1,4.9,1.7,3.5,8.4,5.8,7.3,13.2$ times respectively [77]. There is no clear information about the passing of heavy metals to the medical forms. That is why viruses can cause a serious problems in the production of high-quality medical raw material from infected medicinal plants.

\section{Discussion}

The review of world scientific literature concerning viruses, which infect purple coneflower crops in different countries, showed that almost all of them are considered to be highly harmful and economically important plant viruses. Additionally, four of them (TMV, TSWV, CMV, PVY) occupy the first places in top 10 of the most economically important plant viruses in the world [40]. Such prevalence and harmfulness of these viruses are explained by a wide range of susceptible host plants, wild plants-reservoirs of the infection, and a variety of vector species.

Thus, the analysis of literature showed that all viruses, registered on purple coneflower, are polyphagous. Additionally, the number of viruses known to infect purple coneflower has increased significantly in the last years. Every year new viruses appear in the same agrocoenosis, that was revealed, for example, in Bulgaria, Lithuania and Ukraine $[4,17,18,21,22,24,34$, $62,69]$. In fact, it complicates the prognosis and risk estimation of epiphytoties emergence in these regions.

Detection and circulation of such harmful viruses on commercial plantations of purple coneflower re- 
Purple coneflower viruses: species diversity and harmfulness

quire permanent virological inspections. Cultivation of medicinal plants needs the safety management. In case with medicinal plants using of chemical substances against viruses and their vectors is unacceptable. That is why well-timed detection of plant viruses and information about symptoms of disease, main properties of these pathogens is almost the only method of the prevention of viral infections. Strict control, well-timed diagnostics and disease management of medicinal plants must be applied by the establishments cultivating them. It would reduce the risk of viruses migration into new environments with new vectors that could lead to serious diseases not only of purple coneflower, but also other horticultural or ornamental crops.

A significant reduces of the BAS and accumulation of toxic metals in different medicinal plants under viral infection have been shown in many countries. Today one of the general principles of the modern phytotherapy is medicines safety. That is why much attention of WHO and national Pharmacopoeias is paid to the control of pollution of medicinal raw materials with pesticides, radionuclides, heavy metals, mycotoxins. So, we think that the information about such harmfulness of plant viruses must attract an attention of the drugs producers, creators of the pharmacopoeia papers, state standards and specifications which regulate the quality of medicinal raw material. Virus detection should be included to the worksheets of medicinal crops and to the State Pharmacopoeias as one of key principles for obtaining high yield and high-quality raw material.

\section{REFERENCES}

1. Hudson $J B$. Applications of the phytomedicine Echinacea purpurea (Purple Coneflower) in infectious diseases. $J$ Biomed Biotechnol. 2012;2012:769896.

2. Lim TK. Echinacea purpurea. In: Edible medicinal and nonmedicinal plants. Flowers. Dordrecht: Springer Science Business Media, 2013:340-71.

3. Dikova B. Establishment of some viruses - polyphagues on economically important essential oil-bearing and medicinal plants in Bulgaria. Biotechnology \& Biotechnological Equipment. 2009; 23(Sup 1):80-4.

4. Dikova B, Djourmanski A, Lambev H. Establishment of economically important viruses on Echinacea purpurea and their influence on the yield. In: Proceedings of the confer- ence «Innovative aspects to coneflower study». Ed. Pospelov S. Poltava: Dyvosvit, 2013:36-45.

5. Li GF, Wei MS, Ma J, Zhu SF. First report of broad bean wilt virus 2 in Echinacea purpurea in China. Plant Dis. 2012; 96: 1232

6. Muehle E, Schumann K. [On the presence of cucumber mosaic virus (Marmor cucumeris H.) on Echinacea purpurea (L.) MOENCH]. Pharmazie. 1964;19:417-21.

7. Rangahau $M K$. Echinacea - The purple coneflowers. Crop \& Food Research. 2001;33:12-3.

8. Parmenter G, Burgmans J, Burton L, et al. Production of the medicinal crops Valerian and Echinacea in New Zealand. Proceedings of the Agronomy Society of New Zealand. 1992; 22: 61-5.

9. Yamamoto T, Ishii M, Sasaya T, Iwasaki M. Mosaic disease of Echinacea (Echinacea purpurea, Compositae). Proc Assoc Pl Protec Shikoku. 1993; 28:49-53.

10. Hudaib M, Fiori J, Bellardi MG, Rubies-Autonell C, Cavri$n i V$. GC-MS analysis of the lipophilic principles of Echinacea purpurea and evaluation of cucumber mosaic cucumovirus infection. J Pharm Biomed Anal. 2002;29(6):1053-60.

11. Bellardi $M G$, Rubies Autonell C, Hudaib M, Biffi S. Echinacea purpurea L. Influence of Cucumber mosaic virus (CMV) on the mother tincture. Natural 1. 2001; Dec:74-7.

12. Pellati $F$, Epifano $F$, Contaldo $N$, et al. Chromatographic methods for metabolite profiling of virus- and phytoplasmainfected plants of Echinacea purpurea. J Agric Food Chem. 2011;59(19):10425-34.

13. Beckerman T. Cucumber mosaic virus. Yard \& Garden Line News. 2001; 3(14): 21-3.

14. Horváth J, Baracsi É, Takács A, Kazinczi G, Gáborjányi R, Krajczinger R. Virus infection of ornamental plants in Hungary. Cereal Res Commun. 2006; 34(1):485-88.

15. Voinylo $N V$. Some aspects of protection of floral and ornamental plants against viral diseases in botanical gardens. Zaschita Rasteniy. Minsk. 2006; 30:190-1.

16. Guifen L, Shuifang Z, Qun Z, Zongwei S, Yongjiang Z, Min$g f u$ L. Identification of Cucumber mosaic virus isolated from Echinacea purpurea. Plant protection 1. 2007.

17. Koreneva AA. Biological properties of medicinal plants viruses. $\mathrm{PhD}$ thesis, Taras Shevchenko National University of Kyiv, 2009. 22 p.

18. Samuitienè $M$, Navalinskienè $M$, Jackevičiené E. Detection of Tospovirus infection in ornamental plants by DAS-ELISA. Vagos. 2003; 57:38-42.

19. Dashchenko $A V$. Monitoring of viruses medicinal plants of the family Asteraceae. Karantyn i Zahyst Roslyn 2014;1:10-4.

20. Samuitiene $M$, Navalinskiené $M$. Association of Tobacco rattle and Tobacco ringspot viruses with purple coneflower disease. Botanica Lithuanica. 2010; 16(1):51-6.

21. Navalinskiene $M$, Samuitiene $M$. Dekoratyvinių augalu virusinès ligos ir jų sukèlejjai Lietuvoje. Kaunas, Lithuania: Lietuvoje, 2006; 256 p. 
22. Navalinskiene $M$, Samuitiene $M$. Natural occurrence of Tomato ringspot nepovirus in ornamental plants in Lithuania. Transactions of the Estonian Agricultural University. 2000; 209:140-3.

23. Dikova $B$. Tomato spotted wilt virus on some medicinal and essential oil-bearing plants in Bulgaria. Bulgarian J Agric Sci. 2011;17(3):306-13.

24. Dunich A, Mishchenko L. Heavy metals content in virus infected purple coneflower plants. Bull T Shevchenko Nat Univ Kyiv Ser Biol. 2013; 65(3):22-6.

25. Virus taxonomy. Ninth report of the International Committee on Taxonomy of Viruses. Eds AMQ King, E Lefkowitz, MJ Adams, Carstens EB. Wien: Springer, 2011; 1338 p.

26. Diseases and pests of vegetable crops in Canada. Eds Howard RJ, Garland JA, Seaman WL. The Canadian phytopathological society and entomological society of Canada. 1994. 467 p.

27. Tavoletti $S$, Veronesi $F$, Falcinelli $M$. Intrapopulation variability for AMV symptoms and breeding perspectives in lucerne. In: The Future of Lucerne. Biotechnology, Breeding and Variety Constitution, Proc. X Int. Conf. Eucarpia Medicago spp. Group, Eds. Rotili, P., Zannone, L. ISCF, Lodi:1992:333-5.

28. McLaughlin MR. A greenhouse method for aphid inoculation of Alfalfa mosaic virus in white clover by co-culture of virus, vector, and clover. In: Aphid plant interaction: populations to molecules. Eds Peters DC, Webster JA, Chloubers CS. Stillwater: Okla. Agric. Exp. Stn. OK, 1991. MP-132.

29. Valkonen JPT, Pehu E, Watanabe K. Symptom expression and seed transmission of alfalfa mosaic virus and potato yellowing virus (SB-22) inSolanum brevidens andS. etuberosum. Potato Res. 1992;35(4):403-10.

30. Yin R, Francis F, Bragard C, Liu Y, Chen J. Study on transmission efficiency of CMV transmitted by Myzus persicae from different places. In: Proceedings of $9^{\text {th }}$ International Symposium on Aphids, Beijing, China. 2013:49-50.

31. Davino S, Panno S, Rangel EA, Davino $M$, Bellardi $M G$, Rubio L. Population genetics of cucumber mosaic virus infecting medicinal, aromatic and ornamental plants from northern Italy. Arch Virol. 2012;157(4):739-45.

32. Zhang Y-J, Li G-F, Zhu S-F, Shi Z-W, Li M-F. The analysis on the characteristics of the coat protein genes of Cucumber mosaic virus isolated from Echinacea purpurea Moench. Acta Agriculturae Universitatis Jiangxiensis. 2007; 1: 34-7.

33. Mishchenko LT, Korenieva AA, Molchanets' OV, Boüko AL. [Detection of viral infection pathogens in medicinal plants grown in Ukraine]. Mikrobiol Z. 2009;71(3):55-61.

34. Mishchenko L, Dunich A. Viruses of introducted medicinal plants in Ukraine. J Antivir Antirentovir. 2011; 3(4): 146.

35. de Haan P, de Avila AC, Kormelink R, et al. The nucleotide sequence of the $\mathrm{S}$ RNA of Impatiens necrotic spot virus, a novel tospovirus. FEBS Lett. 1992;306(1):27-32.

36. Ullman DE, Meideros R, Campbell LR, Whitfield AE, Sherwood JL, German TL. Thrips as vectors of tospoviruses. In: Adv Bot Res. 2002;36:113-40.
37. Peters $D$. Tospoviruses: a threat for the intensive agriculture in tropics. In: Loebenstein G, Thottappilly G (ed) Virus and virus-like diseases of major crops in developing countries. Dordrecht, the Netherlands: Kluwer Academic Publishers, 2004:719-42.

38. Turina M, Tavella L, Ciuffo $M$. Tospoviruses in the Mediterranean area. Adv Virus Res. 2012;84:403-37.

39. Martinez RT, Poojari S, Tolin SA, Cayetano X, Naidu RA. First report of tomato spotted wilt virus in Peppers and Tomato in the Dominican Republic. Plant Dis. 2014; 98(1): 163.

40. Scholthof KB, Adkins S, Czosnek H, et al. Top 10 plant viruses in molecular plant pathology. Mol Plant Pathol. 2011;12(9):938-54.

41. Best RJ. Tomato spotted wilt virus. In: Advances Virus Res Eds Smith KM, Lauffer MA. 13. Academic Press, New York, 1968:65-146.

42. Goldbach RW, Peters D. Possible causes of the emergence of Tospovirus diseases. Semin Virol. 1994; 5(2):113-20.

43. Parella G, Gognalons P, Gebre-Selassiè WK, Vovlas G, Marchoux $G$. An update of the host range of Tomato spotted wilt virus. J Plant Pathol. 2003; 85(Spec Iss):227-64.

44. Groves RL, Walgenbach JF, Moyer JW, Kennedy GG. The role of weed hosts and Tobacco thrips, Frankliniella fusca, in the epidemiology of Tomato spotted wilt virus. Plant Dis. 2002; 86(6):573-82.

45. Deangelis JD, Sether DM, Rossignol PA. Transmission of impatiens necrotic spot virus in Peppermint by western flower thrips (Thysanoptera: Thripidae). J Econ Entomol. 1994; 87(1):197-201.

46. Sakurai T, Inoue T, Tsuda S. Distinct efficiencies of Impatiens necrotic spot virus transmission by five thrips vector species (Thysanoptera: Thripidae) of tospoviruses in Japan. Appl Entomol Zool. 2004;39(1):71-8.

47. Naidu RA, Deom CM, Sherwood JL. First report of Frankliniella fusca as a vector of impatiens necrotic spot tospovirus. Plant Dis. 2001; 85(11): 1211.

48. Pelletier $Y$, Nie X, Giguère MA, Nanayakkara U, Maw E, Foottit R. A new approach for the identification of aphid vectors (Hemiptera: Aphididae) of potato virus Y. J Econ Entomol. 2012;105(6):1909-14.

49. The positive sense single stranded RNA viruses. In: Virus taxonomy. Eighth report of the international committee on taxonomy of viruses. Eds. Fauquet CM, Mayo MA, Maniloff J, Desselberger U, Ball LA. London: Elsevier Academic Press, 2005:807-18.

50. Stone WJ, Mink GI, Bergeson GB. A new disease of American spearmint by Tobacco ring spot virus. Plant Dis Rep. 1962; 46:623-24.

51. Fuchs $M$. Association of Tobacco ringspot virus, Tomato ringspot virus and Xiphinema americanum with a decline of highbush blueberry in New York. 21st International Conference on Virus and other Graft Transmissible Diseases of Fruit Crops (July 5-10, 2009, Neustadt, Germany):19. 
Purple coneflower viruses: species diversity and harmfulness

52. Card SD, Pearson MN, Clover GRG. Plant pathogens transmitted by pollen. Australas Plant Pathol. 2007; 36(5):455-61.

53. Sastry $S K$. Seed-borne plant virus diseases. India: Springer, 2013. $327 \mathrm{p}$.

54. Ward LI, Delmiglio C, Hill CF, Clover GRG. First report of Tobacco ringspot virus on Sophora microphylla, a native tree of New Zealand. Plant Pathol. 2009; 58(4):784.

55. Šneideris D, Zitikaitè I, Žižytè M, Grigaliūnaitè B, Staniulis J. Identification of nepoviruses in tomato (Lycopersicon esculentum Mill.). Žemdirbysté $=$ Agriculture. 2012;99(2):173-8.

56. Smith IM, McNamara DG, Scott PR, Holderness M. EPPO. CABI. Quarantine pests for Europe. 2nd edition. Wallingford, UK: CABI International, 1997. $1425 \mathrm{p}$.

57. Harrison BD, Robinson DJ. The tobraviruses. Adv Virus Res. 1978:23:25-77.

58. Macfarlane SA. Tobraviruses - plant pathogens and tools for biotechnology. Mol Plant Pathol. 2010;11(4):577-83.

59. Sigaryova DD, Gubin OI. Phytogelmints: Agents of diseases of ornamental and decorative tropical and subtropical plants in Donetsk botanical garden. Karantyn i Zahyst Roslyn. 2010; 2:18-21.

60. Beczner L, Hamilton RI, Rochon DM. Properties of the Mentha strain of lychnis ringspot virus. Intervirology. 1992;33 (1):49-56.

61. Mishchenko LT, Dunich AA, Dashchenko AV, Zagumennikova TN, Sidel'nikov NI. Viral infections of some medicinal plants and its effect on content of biologically active substances. Problems of biological, medical and pharmaceutical chemistry. 2013; 9:20-5.

62. Sinha A, Srivastava M. Biochemical changes in mungbean plants infected by Mungbean yellow mosaic virus. Int $J$ Virol. 2010;6(3):150-7.

63. Raithak $P V$, Gachande BD. Effect of virus infection on biochemical parameters of tomato plants. Int J Recent Sci Res. 2012; 3(11):997-1000.

64. Mishchenko L, Dunich A, Dashchenko A. Influence of a virus infection contamination on the content of photosynthetic pigments at plants of lophant anisic. Visn Agr Nauk. 2011; 1:28-30.

65. Watson MA, Watson DJ. The effect of infection with beet yellows and beet mosaic virus on the carbohydrate content of sugar beet leaves and on translocation. Ann Appl Biol. 1951; 38(1):276-88.

66. Hudaib M, Fiori J, Bellardi MG, Rubies-Autonell C, Cavri$n i \mathrm{~V}$. GC-MS analysis of the lipophilic principles of Echinacea purpurea and evaluation of cucumber mosaic cucumovirus infection. J Pharm Biomed Anal. 2002;29(6):1053-60.

67. Hudaib M, Cavrini V, Bellardi MG, Rubies-Autonell C. Characterization of the essential oils of healthy and virus infected Echinacea purpurea (L.) Moench plants. J Essenl Oil Res. 2002; 14:427-30.

68. Mishchenko LT, Dunich AA, Sereda AV, Hovaka VV, Veselsky SP. Content of cichoric and caftaric acid in Echinacea purpurea plants infected with viruses. In: Proceedings of Scientific Conference «Biologically active substances: Fun- damental and Applied Problems». (2011, May 23-28, Novy Svet, Ukraine): 292.

69. Mishchenko LT, Hovaka VV, Koreneva AA, Torop VV, Taran $O P$. Content of biologically active substances in virus infected medicinal plants. In: Proceedings of Scientific Conference «Biologically active substances: Fundamental and Applied Problems» (2009, May 25-30, Novy Svet, Ukraine): 132.

70. Bruni R, Bianchi A, Bellardi $M G$. Essential oil composition of Agastache anethiodora Britton (Lamiaceae) infected by Cucumber mosaic virus (CMV). Flavour Fragr J. 2007; 22 (1):67-70.

71. Bruni R, Bellardi MG, Parrella G, Bianchi A. Impact of alfalfa mosaic virus subgroup I and II isolates on terpene secondary metabolism of Lavandula vera D.C., Lavandula $\times$ alardii and eight cultivars of L. hybrida Rev. Physiol Mol Plant Pathol. 2006; 68(4-6):189-97.

72. Crowe FJ, Lommel S, Mitchell A. Evaluation of peppermint field performance from plants regenerated from meristem tip culture, and investigations of virus infection. Mint Industry Research Council (MIRC) 1994 Research Report.

73. Bellardi $M G$, Rubies-Autonell C, Biffi S. Influenza delle infezioni virali sull'olio essenziale di timo (Thymis vulgaris L.). Natural 1. 2001; 9:58-62.

74. Bellardi MG, Rubies Autonell C, Biffi $S$, Cavrini V. Viral infections of Salvia sclarea. The influence of Broad bean wilt virus on the essential oil. Natural 1. 2001; 10:91-5.

75. Hudaib M, Bellardi MG, Rubies-Autonell C, Fiori J, Cavrini $V$. Chromatographic (GC-MS, HPLC) and virological evaluations of Salvia sclarea infected by BBWV-I. Farmaco. 2001;56(3):219-27.

76. Dunich AA, Dashchenko AV, Mishchenko LT. Content of microelements in Echinacea purpurea plants under biotic stress. Acta Physiol Plant. 2012; 34(1 Suppl):90-1.

77. Dunich AA, Dashchenko AV, Mishchenko LT. Effect of viral infection on elements content in Lophanthus anisatus plants. Agroekol Zh. 2010; suppl.:92-5.

\section{А. А. Дуніч, Л. Т. Міщенко}

\section{Віруси ехінацеї пурпурової: видове різноманіття та шкодо чинність}

У світі все більш гострою проблемою при промисловому вирощуванні лікарських рослин стають вірусні захворювання. Встановлено, що в останні роки в багатьох країнах число вірусів, що уражують ехінацею значно зросла. Незважаючи на це, науковцям бракує цілісного огляду світової наукової літератури про вірусні захворювання, які інфікують дану цінну лікарську культуру. Метою роботи $\epsilon$ зведення основної інформації про віруси, що заражають ехінацею пурпурову в світі. Аналіз літератури показав, що ехінацея пурпурова уражається 10 вірусами 3 сімейств Bromoviridae, Bunyaviridae, Secoviridae, Potyviridae, 
Virgaviridae, практично всі вони визначені шкодочинними фітовірусами. Крім того, чотири серед них (TMV, TSWV, CMV, PVY) займають перші позиції в 10-ці найбільш науково і економічно значущих вірусів рослин в світі. Таке поширення та шкодочинність цих вірусів пояснюється широким колом чутливих рослин-господарів, диких рослин i бур'янів - резервантом інфекції, а також великою кількістю векторів. Дослідження вірусологів 3 декількох країн показують, що симптоматика вірусних інфекцій ехінацеї з роками стає більш складною. Щорічно діагностуються нові віруси ехінацеї, що ускладнює прогнозування та оцінку ризику появи епіфітотій в певних регіонах, як наприклад, це було зареєстровано в Литві, Україні та Болгарії. У статті детально представлені симптоми вірусних хвороб ехінацеї, основні властивості кожного вірусу і дані про їхній вплив на концентрацію біологічно активних речовин і важких металів рослин.

Кл юч о в і слов а: ехінацея пурпурова, віруси рослин, видове різноманіття, біологічно активні речовини, важкі метали.

\section{А. А. Дунич, Л. Т. Мищенко}

\section{Вирусы эхинацеи пурпурной: видовое разнообразие и вредоносность}

В мире все более острой проблемой при промышленном выращивании лекарственных растений становятся вирусные заболевания. Установлено, что во многих странах число ви- русов, поражающих эхинацею в последние годы значительно возросло. Несмотря на это, цельный обзор мировой научной литературы о вирусных заболеваниях, инфицирующих эту ценную лекарственную культуру, отсутствует. Целью работы является суммировать основную информацию о вирусах, заражающих эхинацею пурпурную в мире. Анализ литературы показал, что эхинацея пурпурная поражается 10 вирусами из семейств Bromoviridae, Bunyaviridae, Secoviridae, Potyviridae, Virgaviridae. Практически все они определены вредоносными фитовирусами. Кроме этого, четыре среди них (TMV, TSWV, CMV, PVY) занимают первые позиции в 10-ке наиболее научно и экономически значимых вирусов растений в мире. Такое распространение и вредоносность этих вирусов объясняется широким кругом чувствительных растений-хозяев, диких растений и сорняков - резервантов инфекции, а также большим количеством векторов. Исследования вирусологов из нескольких стран показывают, что симптоматика вирусных инфекций эхинацеи с годами становится более сложной. Ежегодно диагностируются новые вирусы эхинацеи, что усложняет прогнозирование и оценку риска появления эпифитотий в определенных регионах, как например, это было зарегистрировано в Литве, Украине и Болгарии. В статье детально представлены симптомы вирусных болезней эхинацеи, основные свойства каждого вируса и данные о их влиянии на концентрацию биологически активных веществ и тяжелых металлов растениях.

Кл юч ев ы е сл о в а: эхинацея пурпурная, вирусы растений, видовое разнообразие, биологически активные вещества, тяжелые металлы.

Received 10.12.2014 